\title{
Categories and activities in the area of inclusion of people with disabilities found within commune strategies - selected examples based on the communes of the counties of $\dot{Z}$ ywiec and Cieszyn districts
}

\begin{abstract}
Sebastian Mrózek, Categories and activities in the area of inclusion of people with disabilities found within commune strategies - selected examples based on the communes of the counties of Żywiec and Cieszyn districts. Interdisciplinary Contexts of Special Pedagogy, no. 27, Poznań 2019. Pp. 29-52. Adam Mickiewicz University Press. ISSN 2300-391X. e-ISSN 2658-283X. DOI: https:// doi.org/10.14746/ikps.2019.27.02
\end{abstract}

The issue of strategies of activities aimed at people with disabilities living in the relevant communes is a topic rarely undertaken in discourse of special pedagogy. These issues are found among the other activities that local government entities are contemporary obligated to implement, and span solutions and activities in the area of inclusion for people with disabilities. It is hence important to know and overcome problems and barriers that hinder or block the right functioning of people with disabilities. Some of solutions and activities are contained in the two types of communal strategic documents, these are: Commune Development Strategies and Strategies for solving social problems.

The article consists of three parts. The first covers the characteristics of communal strategies and social policy towards people with disabilities. The second part presents the assumptions and results of research based on a qualitative analysis of strategic documents of 27 communes (about 3900 pages of documents) in terms of categories and activities regarding the inclusion of people with disabilities. The whole is summarised in the final conclusions. The aim of the study is preliminary 
recognition of exemplary activities found in the strategies of communes from the counties of Żywiec and Cieszyn. Text notes the "good practices" and noteworthy solutions for inclusion applied by local government entities with respect to people with disabilities.

KEY WORDS: commune, Strategies of development, Strategies for solving social problems, people with disabilities, good practices in the area of inclusion

\section{Introduction}

When constructing a vision of the local development for the coming years, and designing activities characterised by actions against social problems (e. g. alcohol abuse, violence, unemployment, and among them sadly still-disabilities), local government entities utilise the strategic approach. Both local development as well as attempts at countering social problems are long-term processes, requiring ordered and regularly updated solutions. ${ }^{1}$ In order to precisely describe development goals, a prior verification of the situation at hand and the analysis of (very diverse) needs and expectations of the individual social strata is required. Development in itself should describe progress, and the solutions implemented and identified with it should contribute to the improvement of life quality, in particular of groups threatened by exclusion and disfavoured ones.

The meaning of the term "strategy" has evolved over the years, changing its location within fields. In the original meaning, the word stems from the Greek word strategom. This was a concept related directly to military activity. It described the art that characterised generals fighting against enemy forces. As spontaneity in this regard did not yield the expected results, the decision was made to develop meticulous, thought-out action plans and relevant unit

${ }^{1}$ Conf. T. Wołowiec, D. Reśko, Strategia rozwoju gminy jako narzędzie zarządzania zmiana gospodarcza, "Zeszyty Naukowe WSEI seria: EKONOMIA", 5(2/2012), pp. 61-89. 
manoeuvres. Contemporarily, the concept of strategy plays a powerful role in economy, marketing or social policy - hence in areas that fit very well in the activity of local government entities. Strategies are used to win 'battles' for something socially significant. One cannot commence developing a strategy if one is not certain what one wants to achieve as a result. Developing the strategy, one must not show indecision, obfuscate any lack of knowledge about actual objectives or, including grandiose words, hoping at the same time for other gains. When creating a responsible and valuable strategy, one needs to keep in mind all the time the recipients of the services to be provided. Their problems, needs, deficits and resources should constitute the core, around which the detailed action plan would be developed. ${ }^{2}$

According to business historian Alfred D. Chandler (1962), strategy is a "process of determination of the fundamental, longterm objectives of an organisation". It includes the assumption of specific directions of action and the allocation of resources necessary to achieve those objectives. ${ }^{3}$ Economist and sociologist Herbert Simon (1976) in turn defines it as a "string of decisions describing behaviour in certain periods of time". 4

Strategy is hence understood as a kind of action plan of an organisation, related to its (contemporary and future) status in the environment, as well as a fairly stable and specific mode of functioning. It is a coherent concept approved by the organisation's leadership, the implementation of which will ensure the achievement of basic and long-term goals within a specific chosen domain. ${ }^{5}$

${ }^{2}$ M. Grewiński, A. Karwacki, Strategia - istota, reguty i wyzwania implementacji ze środowiska biznesu do polityki społecznej, [in:] Strategie w polityce społecznej, ed. by M. Grewiński, A. Karwacki, publication co-financed from resources of the European Social Fund as part of the Human Capital Operational Programme, priority VII, activity 7.1.3., Mazowieckie Centrum Polityki Społecznej, Warszawa, 2011, pp. 16-18.

${ }^{3}$ A.D. Chandler, Strategy and Structure, MIT Press, Cambridge, Mass 1962, p. 13.

${ }^{4}$ H.A. Simon, Działanie administracji, PWN, Warszawa 1976, p. 163.

${ }^{5}$ K. Obłój, M. Trybuchowski, Zarządzanie strategiczne, [in:] Zarządzanie. Teoria i praktyka, ed. by A.K. Koźmiński, W. Piotrowski, Wydawnictwo Naukowe PWN, Wydanie piąte zmienione, Warszawa 2006, p. 127. 
The construction of a strategy is a task requiring particular balance in terms of development of activities for marginalised groups or those threatened by broadly understood exclusion - e. g. persons with disabilities. Local government entities, deciding to utilise the strategic approach, face a grand challenge burdened by huge responsibility.

The recent few decades are a time of intense social, cultural or economic changes in the area of normalisation of the environment of life and the equalisation of chances of persons with disabilities. Social policy began to play a significant role in terms of role in terms of issues of disabilities. The changes described above, however, are characterised by the fact that the influences they exhibit emerge quickly, sometimes even unexpectedly, and if they are not properly controlled - they disappear just as quickly or are marginalised. In light of such a changing state of affairs, particular significance is gained by the development of mechanisms serving the perspective activities towards persons with disabilities. These activities should guarantee durability and permanence of implemented solutions, and be fairly resistant to uncontrolled political or economic changes. The tools that initiate or implement diverse ideas in the social, educational or therapeutic sense are social policy strategies, constructed on the national or local level. ${ }^{6}$ Issues related to the implementation of social activities on the communal level are particularly interesting. Local government entities ${ }^{7}$ are obligated to plan and implement a range of public activities (also in the area of functioning of persons with disabilities), which are found in two types of commune strategy documents; these are: Commune Development Strategies i Strategies for solving social problems. These are documents

6 Z. Gajdzica, Social policy of the local government unit as an initiator of good practices in activating the disabled, [in:] "Osoba niepełnosprawna w środowisku lokalnym. Problemy Edukacji, Rehabilitacji i Socjalizacji Osób Niepełnosprawnych”, ed. by I. Fajfer-Kruczek, Wydawnictwo Uniwersytetu Śląskiego, Katowice 2015, vol. 20, pp. 14-15.

${ }^{7}$ Local government entities are authorities that are not direct representatives of the national government. 
that should constitute a source of good practices and the basis for implementation of necessary changes. ${ }^{8}$

The present study is composed of three parts. The first attempts to characterise Commune Development Strategies and Strategies for solving social problems. The core of the study is the second part, encompassing the presentation of results of own research. This research seeks to find responses to questions about superordinate categories and activities within them, which in the context of inclusion of persons with disabilities are found within strategies. The entirety is summarised by closing conclusions.

The objective of the presented study is an attempt at a fragmentary, preliminary analysis of example activities towards persons with disabilities included in strategic documents of communes ${ }^{9}$ that make up two neighbouring counties: Żywiec (15 communes) and Cieszyn (12 communes). I am interested in the categories of the process of inclusion of this group that the mentioned activities are executed in, and the form they take.

\section{Commune strategies - properties and significance in the perspective of inclusion of persons with disabilities}

In relation to the tendency of decentralisation of government power ${ }^{10}$ entities that are in contemporary democratic states engaged in the execution of public tasks include, among others, local

${ }^{8}$ Conf. Z. Gajdzica, S. Mrózek, Cele i zadania działań edukacyjnych w obszarze ksztatcenia uczniów z niepetnosprawnościq oraz edukacji o niepetnosprawności zawarte w strategiach rozwoju gmin a problem rozwoju edukacji inkluzyjnej, [in:] Z. Gajdzica (ed.) „Studia Pedagogiczne. Wokół wyzwań pedagogicznych” vol. LXX, ed. by Z. Gajdzica, Polska Akademia Nauk. Komitet Nauk Pedagogicznych, Cieszyn 2017.

${ }^{9}$ This study refers to categories and activities for the people with disabilities located in two types communal strategic documents, these include: Commune Development Strategies and Strategies for solving social problems.

${ }^{10}$ Conf. M. Grewiński, Wieloaspektowa polityka spoteczna. O przeobrażeniach państwa opiekuńczego, Wyższa Szkoła Pedagogiczna Towarzystwa Wiedzy Powszechnej w Warszawie, Warszawa 2009, pp. 162-166. 
government entities. Their satisfaction of the group needs of various social groups (with the mentioned strata not only including disabled persons) should be achieved by way of implementation of planned, varied activities. It is expected for these to be designed on the basis of fundamental information and thorough analyses. ${ }^{11}$ Assuming such a form, activity of local government entities also forms a part of the development of the culture of inclusion related to the inclusion of representatives of disfavoured groups. ${ }^{12}$ Disability continues to be one of the factors that strongly marginalise, and at times even completely exclude, an individual from public life. For this reason, it and the conditions related to it have become subjects of interest of social policy makers. They are primarily focused on achieving efficiency of activities reducing the level of social pathologies. ${ }^{13}$

Local government entities, establishing local policies with respect to disabled persons, are obligated to include and enrich solutions of inclusion, which stems already from such fundamental documents as the Universal Declaration of Human Rights (1948), Standard Rules on the Equalisation of Opportunities for Persons with Disabilities (1993) or the UN Convention on the Rights of Persons with Disabilities (2006). ${ }^{14}$ A particular role is played by processes of cognition and attempts at conquering issues and barriers that hinder the correct functioning of persons with disabilities. Knowledge about social needs and issues guarantees suitable efficiency of the planned and implemented support activities. Neces-

11 A. Kołomycew, B. Kotarba, Interes polityczny w realizacji polityki oświatowej, Wydawnictwo Naukowe SCHOLAR, Warszawa 2018, p. 82.

12 Conf. B. Bąbska, Rozpoznanie potrzeb grup marginalizowanych $i$ wykluczonych, [in:] Środowiskowe ustugi społeczne - nowa perspektywa polityki i pedagogiki społecznej, ed. by M. Grewiński, B. Skrzypczak, Wyższa Szkoła Pedagogiczna TWP w Warszawie, Warszawa 2011, pp. 135-154.

${ }_{13}$ M. Lejzerowicz, A. Książkiewicz, Osoba z niepetnosprawnościa a instytucje pomocowe, Wydawnictwo Gaskor, Wrocław 2012, pp. 33-34.

14 More: M. Radziejewska, A. Mazurczak, Konwencja o Prawach Osób Niepetnosprawnych. Poradnik RPO, Biuro Rzecznika Praw Obywatelskich, Warszawa 2013. 
sary is thus cohesion between the needs of the benefactor and the types of aid provided. Inclusion applies to all areas of daily life of persons with disabilities. ${ }^{15}$ One of its objectives is sensitising the local community to issues of functioning of citizens with disabilities. It is only then that a permanent improvement of the social situation and the perception of these people, devoid of excess stereotyping, and, accordingly, aversion, fear and avoidance of contact, may emerge.

Commune authorities, represented e. g. by commune and urban social aid facilities, as well as commune head offices, play a fundamental role in the provision of financial, legal, psychological or paedagogical aid. ${ }^{16}$ Still, of importance are forms of aid provided by the family, professional circles, organisations as well as local communities that are actually engaged in the solution of persons suffering from disability and ready for mutual coexistence, based on full acceptance. ${ }^{17}$ In the age of inclusion, the communes should thus offer an entire spectrum of aid and support work. Some of them are strongly accented in the Commune Development Strategies and in Strategies for solving social problems.

The creation and planning of strategies has significant importance from the point of view of local policy. Solutions offering high efficiency in the commercial or business sector have been in Western Europe introduced in social policy at least three decades ago, in Poland this period is about a decade. Strategies delineate fields of cooperation and engagement of individual entities to achieve the set objectives. ${ }^{18}$

${ }^{15} \mathrm{~K}$. Frysztacki, Wokót istoty „społecznego wykluczenia” oraz "społecznego właczenia", [in:] Ekskluzja i inkluzja społeczna. Diagnoza - Uwarunkowania - Kierunki działań, ed. by J. Grotowska-Leder, K. Faliszek, Wydawnictwo Edukacyjne Akapit, Toruń 2005 , p. 18.

16 B. Kołaczek, Polityka społeczna wobec osób niepetnosprawnych, Instytut Pracy i Spraw Socjalnych, Warszawa 2010, p. 29.

17 M. Lejzerowicz, I. Książkiewicz, Osoba z niepetnosprawnością..., op. cit., p. 135.

18 M. Grewiński, A. Karwacki, Strategia - istota, reguty i wyzwania..., op. cit., p. 11. 
The construction of Local Development Strategies is a fairly fresh planning experience of Polish communes, counties and voivodeships. It describes a long-term action plan of the commune (the local community), which includes three components, that is ${ }^{19}$ :

- the establishment of development objectives;

- the description of resources and modes of achievement of objectives;

- the description of relations with the environment.

The content of Strategies for solving social problems in turn spans a social aid programme, prevention, solutions to social problems. Their fundamental objective is the integration of persons and families from risk groups. The fundamental area of aid activity includes social and professional activation of benefactors and the creation of conditions for education, meaning "public education". Professional therapeutic aid and integrated psychological aid are also required. ${ }^{20}$

Methodologies of working on strategies can be varied. The relatively highest rated is the mode of their development that factors in the commune leaders, commune office employees, employees of local government entities, external consultants and representatives of political parties, unions, foundations, the catholic Church, local business, community leaders. The social span of the process of development of the strategy increases the level of engagement of all entities in the execution of the set objectives and raises the probability level of achievement of the assumed objectives and goals. ${ }^{21}$

It must be stressed, however, that contemporarily the visions of development of communes for the subsequent years are constructed not only by representatives of local governments and aid institu-

19 A. Lipiński, Strategie rozwoju lokalnego, [in:] Strategie rozwiązywania problemów społecznych w subregionie radomskim, ed. by K. Głąbicka, Biuletyn Informacji PTPS, Radom 2011, p. 27.

${ }^{20}$ K. Głąbicka, Strategie rozwiązywania problemów społecznych jako przykład realizacji lokalnej polityki społecznej, „Wrocławskie Studia Politologiczne”, 15/2013, p. 190.

${ }^{21}$ E. Pawłowska, Strategia rozwiązywania problemów społecznych - nowa jakość ustug społecznych w Szklarskiej Porębie, [in:] Środowiskowe ustugi społeczne - nowa perspektywa polityki i pedagogiki społecznej, ed. by M. Grewiński, B. Skrzypczak, Wyższa Szkoła Pedagogiczna TWP w Warszawie, Warszawa 2011, p. 294. 
tions, but also "marketing specialists". At times they contribute to the negative phenomenon that is the simulation of certain activities. Such processes are not only ethically questionable, but also inefficient, not to mention that persons (being hypothetical benefactors) interested in specific tasks (the strategies are publicly available usually in public information bulletins ${ }^{22}$ of the relevant commune or social organisation) that in reality are not implemented at all could just feel cheated.

In the social world, simulated activities are important, but also "awkwardly", negatively assessed functions - they maintain the life of social systems. Their excess presence may leave far-fetching and unwanted effects that include the solidification of simulations and social opposition. People seeking fake and fraudulent activities stop trusting each other, a fact that leads to deepening social disintegration. ${ }^{23}$

It is worth analysing, what categories related to the inclusion of persons with disabilities are found within commune strategic documents, and what are the activities listed within them. I would like for the present study and the results of the pilot research included in them to form an introduction to a broader diagnosis concerning the detailed analysis of the situation of people with disabilities in the local community and the verification of the prevalence of the listed activities with respect to this group in the strategic documents of the individual communes.

\section{Own research concept}

The efficiency of solving of problems of local communities determines at the same time the proper operation of the local entity

${ }^{22}$ Public Information Bulletins are information publications with key data under care of the authorities.

${ }^{23}$ Conf. D. Trawkowska, Działania pozorne w pomocy społecznej - przypadek (i przypadtość) pracy socjalnej, „Problemy polityki społecznej. Studia i dyskusje”, 10/2007, Dom Wydawniczy „Elipsa”, Warszawa 2007, p. 132. 
that is the commune. These are a socially significant issues, because in terms of the existence of persons with disabilities, they call for respect, dignity and the equalisation of chances. This is the basis for broader musings on the efficient use of social resources and the increase of social integration. ${ }^{24}$

Within the scope of the selected research topic, I was primarily interested in issues concerning categories and related inclusion work aimed at persons with disabilities, found within two types of commune strategies: Commune Development Strategies and Strategies for solving social problems. The research issues are described by two basic questions:

- What superordinate categories related to the inclusion of people with disabilities are reflected in commune strategies?

- What activities reinforcing tendencies of inclusion towards persons with disabilities were inscribed in the analysed commune strategies?

In the search for answers to research problems described in this way, the qualitative analysis encompassed strategies of all communes from the area of two counties in the Silesian voivodeship of Poland: Żywiec county (15) and Cieszyn county (12). ${ }^{25}$ The selection of the area was purposeful - it allows for the collection of information on the basis of an analysis of strategies of neighbouring counties that are mutually comparable in terms of demography and administration. A further phase of preliminary work was also described, an amendment to the current analyses. This shall be exploratory and diagnostic research. It is related to the verification of the frequency of projects concerning activities for people with disabilities in selected communes of Poland, broken down by rural, urbanrural and urban communes, along with a mutual comparison of the individual Polish counties. The objective here shall be the discovery and description of provisions concerning persons with disabilities

${ }^{24}$ K. Głąbicka, Strategie rozwiązywania problemów społecznych..., op. cit., p. 183.

${ }^{25}$ A list of the analysed strategies is found after the literature list. A total of almost 3900 pages of documents were studied. 
in two types of commune strategies; detailed knowledge and analyses of conditions of creation of the commune strategies and the inclusion within them of the issue of disability; identification of indicators of implementation of the suggested activities. Due to the limited scope of the study, the results of the mentioned analysis shall constitute the object of a separate publication.

The basis for the analysis of the content of strategic documents is the creation of a system of categories. ${ }^{26}$ The creation of a category key entails the collection of a set of categories concepts that deal with the analysed content. In this regard, two techniques of categorisation may be used: emergent - developing the key only on the basis of the collected empirical material (typical for qualitative studies) and a priori - creation of the key on the basis of one's knowledge, only before commencement of the encoding proper (approach typical for quantitative studies). ${ }^{27}$ In the qualitative analysis, the category key is the study result described within itself. It is like a bullet list of issues discussed in the research process, and at the same time it seeks to present its maximum diversity. Qualitative studies, the establishment of the key is based on a multiple, thorough reading of the entirety of the research material, with the consideration of repetition of certain topical categories, their mutual ties or the discovery of diversity. ${ }^{28}$ I assume that as a result of the ordering qualitative analysis of the commune strategies, categories shall be discerned related to broadly-understood inclusion of persons with disabilities, and the individual categories shall encompass activities in this regard. I therefore assume that social inclusion is a process, the main objective of which is disabled persons acquiring the capacities and skills necessary for holistic participation in the economic, social and cultural life, along with the maintenance and

${ }^{26}$ Conf. E. Babbie, Podstawy badań spotecznych, Wydawnictwo Naukowe PWN, Warszawa 2013, pp. 428-434.

${ }^{27} \mathrm{~K}$. Szczepaniak, Zastosowanie analizy treści w badaniach artykutów prasowych refleksje metodologiczne, "Acta Universitatis Lodziensis Folia Sociologica”, no. 42/2012, Wydawnictwo Uniwersytetu Łódzkiego, pp. 88-89.

${ }^{28}$ Ibidem, pp. 98-99. 
permanent continuation of their standards of living that are considered normal in the given society. At the same time, a different aspect of related work is the increase in participation of persons with disabilities in decision processes influencing their lives, and access to fundamental rights. ${ }^{29}$ The main objective of the present preliminary study is the initial description of superordinate categories related to inclusion and work in this regard for the benefit of the group of persons described in commune strategies. The acquired information shall allow one to sketch out the fundamental areas of influence of local government entities and the projects undertaken in their areas that are useful in the creation of an environment that would be friendly for persons with disabilities. Such a commencement forms the basis for broader and more commonplace solutions that could be referred to as good practices in the area I am interested in.

\section{Presentation and discussion of research results}

Below I present ordered tables concerning categories related to the inclusion of persons with disabilities and activities within commune strategies of all communes of the counties of Żywiec and Cieszyn discovered within them. According to the quoted assumptions, the frequency of the provisions I am interested in shall constitute the subject of a separate study - and was not presented here.

In course of the performance of the quality analysis to arrange the provisions of strategic documents in order, and in relation to the concept of social inclusion described earlier, I have discerned the following categories ${ }^{30}$ :

${ }^{29}$ Conf. A. Zajadacz, J. Śniadek, Modele niepetnosprawności jako determinanty przeobrażeń struktury podażowej rynku turystycznego dostępnego dla osób niepetnosprawnych, [in:] Ewolucja podaży i popytu w turystyce, ed. by B. Walas, J. Sobczuk, Wydawnictwo Wyższej Szkoły Turystyki i Ekologii, Sucha Beskidzka 2014, pp. 215-216.

30 The entries in the strategies usually take on the form of a set of activities, frequently related to each other - hence the selections are verb-based. 
- Informing persons with disabilities;

- Arrangement of aid and support for persons with disabilities;

- Equalisation of areas of deficits related to the functioning of persons with disabilities;

- Activation of persons with disabilities and the local community;

- Execution of support, aid and diagnostic forms for persons with disabilities.

Table 1. Category: "Informing persons with disabilities" and activities within it

\begin{tabular}{|l|}
\hline \multicolumn{1}{|c|}{ Informing persons with disabilities } \\
\hline - Informing persons with disabilities on their rights, available forms of aid and \\
support, their privileges, entailing the creation in the individual communes of \\
special information points for this group of people;
\end{tabular}

Source: own work.

Table 2. Category: "Arrangement of aid and support for persons with disabilities" and activities within it

Arrangement of aid and support for persons with disabilities

- Organising of cultural and educational events that persons with disabilities actively and passively take part in;

- Organising for persons with disabilities of support groups with local community centres, occupational therapy workshops, day aid centres that offer psychological and education aid;

- Organising of social integration clubs that take into account the situation of persons suffering from disabilities; 


\begin{tabular}{|l|}
\hline \multicolumn{1}{|c|}{ Arrangement of aid and support for persons with disabilities } \\
\hline - Organising of social services and increasing their availability for persons with \\
disabilities; \\
\hline - Organising of early support for child development; \\
\hline - Organising of free time and rest of persons with disabilities (trips, excursions, \\
including integration events - together with fully-able persons); \\
\hline - Organising of courses and seminars improving the competences of persons with \\
disabilities in the social, education or professional area;
\end{tabular}

Source: own work.

Table 3. Category: „Equalisation of areas of deficits related to the functioning of persons with disabilities" and activities within it

- Equalisation of areas of deficits related to the functioning of persons with disabilities

- Equalisation of education chances and availability of education in the commune in the form of integration or public schools;

- Equalisation of access to information - issuing brochures, bulletins, newsletters, creation of specialised websites where people with disabilities could find the information they need;

- Equalisation of the qualify of life of persons with disabilities through diverse forms of aid: financial, emotional, information, spiritual;

- Equalisation of availability of mobility by removal of architectural and transport barriers in public spaces, construction of new and refurbishment of old buildings with consideration of simplifications for persons with disabilities (driveways, elevators, handrails, etc.);

- Equalisation of social participation of persons with disabilities through actively engaging them in the life of the local community and the establishment in local communities of a positive image of persons with incomplete abilities through the organisation of meetings with disabled sportspeople, actors, singers.

Source: own work. 
Table 4. Category: "Activation of persons with disabilities and the local community" and activities within it

\begin{tabular}{|l|}
\hline \multicolumn{1}{|c|}{ Activation of persons with disabilities and the local community } \\
\hline - $\begin{array}{l}\text { Activation of commune inhabitants to commence aid work, support for disa- } \\
\text { bled locals: volunteer work, help in terms of care and rehabilitation, work for } \\
\text { the benefit of associations, organisations, the Church; }\end{array}$ \\
\hline - $\begin{array}{l}\text { Activation of persons with disabilities to undertake projects (at a level they } \\
\text { could achieve) related to own personal development: education, courses, train- } \\
\text { ing, gainful employment. }\end{array}$ \\
\hline
\end{tabular}

Source: own work.

Table 5. Category: „Execution of support, aid and diagnostic forms for persons with disabilities" and activities within it

- Execution of support, aid and diagnostic forms for persons with disabilities

- Execution of local government programmes for the social and professional activation of persons with disabilities;

- Execution of training to increase qualifications of employees of institutions or facilities dealing with persons with disabilities;

- Implementation of standards and services for persons with disabilities at the EU level, usage of good and efficient examples;

- Execution of permanent and regular diagnoses of the local community to monitor the situation of persons with disabilities in the communes.

Source: own work.

The analysis of provisions concerning the strategic documents of the communes in the counties of Żywiec (15 communes) and Cieszyn (12 communes) had shown that local government entities offer varied activities that encompass inclusion for the mentioned group of people. It must be stressed that the assignment of individual activities to the mentioned categories is conventional, as in terms of content and significance they frequently repeat one another in the documents. This, however, forms a fundamental model, indicating the path that local government entities have chosen in terms of issues of functioning of disabled inhabitants, utilising their strategic approaches. 
The individual activities within the categories related to the inclusion of persons with disabilities are formulated in a very general manner that is hard to differentiate. This is doubtless the weakest property of the analysed documents - even despite great differences in terms of content of the provisions and their large number. However, this is no typical phenomenon, and this method is frequently used by local government entities. ${ }^{31}$ Provisions offering little precision gravely hinder or even prevent binding accounting of communes/ counties with respect to the solutions suggested in the strategies. Without precise knowledge and thorough analyses in a smaller area, it is very difficult to clearly state, what kind of inclusion work towards persons with disabilities is actually implemented, and what kind of work is just a simulation.

Fuzzy provisions around the suggested solutions, frequently devoid of clearly described indicators, do not make it easy for persons with disabilities and their caretakers to use them fully and without problems. The analysis of the strategic documents themselves can only suggest a certain outline of help that should be offered. In this regard (on the basis of the analysed counties), the situation requires further work, in particular more detailed descriptions - so that persons with disabilities and their next of kin are burdened by as little effort of organisation as possible. Their life situation is already sufficiently complicated.

A positive phenomenon related to the analysis of activities in the individual categories is the fact that the communes (at least in theory) utilise a holistic and interdisciplinary approach in order to simplify and increase social participation of persons with disabilities. This is very important from the point of view of inclusion, which, however, tends to be treated by local government entities persistently and as a replacement of integration - while in fact, this is a great simplification and a wrong interpretation of the actual state of affairs. ${ }^{32}$ How-

31 Conf. Z. Gajdzica, S. Mrózek, Cele i zadania działań edukacyjnych w obszarze kształcenia uczniów z niepetnosprawnościa..., op. cit., pp. 284-285.

32 Conf. B. Grochmal-Bach, A. Czyż, A. Skoczek (ed.), Segregacja. Integracja. Inkluzja, Akademia Ignatianum, Wydawnictwo WAM, Kraków 2013. 
ever, the categories related to the inclusion of persons with disabilities themselves, such as: "informing"; "organising"; "equalisation"; "implementation"; "activation", utilise numerous activities, the actual and regular implementation of which may contribute to a fuller participation by persons with disabilities in social life, or prevent their marginalisation. Noteworthy is the fact that the mentioned examples of activities refer to diverse and significant spheres of life: education, work, free time, the family, and more specialised ones, stemming directly from the disability, such as: revalidation, rehabilitation or medical care.

A sign of responsibility by local government entities is also addressing their offer not only directly to persons with disabilities, but also to the local community of the communes. Such an approach contributes to the reinforcement of social cohesion or countering false stereotypes. It does not excessively burden the disabled person as responsible for the situation in which they have found themselves, and which they have to cope with themselves. The mentioned aid uses not only the work of professional and trained associations and institutions, but ascribes more and more meaning to informal human relations that acquire a natural, and, primarily, more authentic form of aid.

\section{In lieu of an conclusion}

The examples presented in the study are the base model for activities characterised by inclusion with respect to persons with disabilities in the commune strategies within two counties: Żywiec and Cieszyn. In course of the qualitative analysis of the strategic documents, identified were fundamental categories related to inclusion. They in turn were assigned precisely described activities suggested by local government entities. The collected material is an introduction to further analyses of the topics that constitute the placement of the issues of disability within commune strategies. Assuming this task - one very important and bound by social responsibility, repre- 
sentatives of local government entities need to remember many important conditions of establishment of good strategies.

Inefficient and ethically questionable is the simulation of activities without real implementation in the environment. The significance of strategies and of the content in them is them hypothetical and postulative. Solidified simulations in such socially delicate matters strip the entities of their social trust. ${ }^{33}$

The establishment of strategies is a long-term procedure. Offering perspective activities for a defined group, one must know their needs in detail. Representatives of communes should regularly diagnose and monitor social groups threatened by exclusion or problems. In case of persons with disabilities, e. g. through actual contact with such people or their legal caretakers, as well as through cooperation with institutions offering a certain kind of support.

The solutions foreseen in the strategies for persons with disabilities must do away with general provisions and the avoidance of measurable indicators. This significantly hinders verification - and is also a weakness of the strategies analysed for the present study. Of importance is also periodicity and the ability to draw conclusions. Strategies remain in force for a specific period of time. It is significant for subsequent editions to comment on the efficiency of activities offered in the previous issue of the document, and to contain modifications - the addition of new or the cancellation of such activities which, for certain reasons, failed to yield results.

In case of disability, strategies should be developed with active participation of disabled persons and their caretakers as well as representatives of: aid institutions, the scientific community, the local community or people who are aware of the actual needs of persons with disabilities. Considered must also be contemporary tendencies in special education. The analysed strategies do not offer a significant delineation between integration and inclusion. In these documents, these concepts are generally treated as synonyms.

33 Z. Gajdzica, Social policy of the local government unit..., op. cit., pp. 14-15. 
To summarise - the analysed area requires bringing into order and a thorough verification of solutions offered by local government entities. A significant role is played by regular adaptation and analyses of the actual needs of benefactors. Analyses of the strategic documents in terms of inclusion is still burdened by much randomness and lack of clarity, the collected material, however, allows the conclusion that presently local government entities offer quite varied activities in many areas of daily life of persons with disabilities, which facilitate inclusion. Development Strategies and Strategies for solving social problems can hence constitute their real source, under the condition that the authors and agents assume a responsible, competent and caring attitude towards citizens with disabilities.

\section{Bibliography}

[1] Babbie E., Podstawy badań społecznych, Wydawnictwo Naukowe PWN, Warszawa 2013.

[2] Bąbska B., Rozpoznanie potrzeb grup marginalizowanych i wykluczonych, [in:] M. Grewiński, B. Skrzypczak (ed.), „Środowiskowe usługi społeczne - nowa perspektywa polityki i pedagogiki społecznej", Wyższa Szkoła Pedagogiczna TWP w Warszawie, Warszawa 2011, pp. 135-154.

[3] Chandler A.D., Strategy and Structure, MIT Press, Cambridge, Mass 1962.

[4] Frysztacki K., Wokót istoty "społecznego wykluczenia" oraz "społecznego włączenia”, [in:] Ekskluzja i inkluzja spoteczna. Diagnoza - Uwarunkowania - Kierunki dziatań, ed. by J. Grotowska-Leder, K. Faliszek, Wydawnictwo Edukacyjne Akapit, Torun 2005, p. 18.

[5] Gajdzica Z., Social policy of the local government unit as an initiator of good practices in activating the disabled, [in:] „Osoba niepełnosprawna w środowisku lokalnym. Problemy Edukacji, Rehabilitacji i Socjalizacji Osób Niepełnosprawnych", ed. by I. Fajfer-Kruczek, Wydawnictwo Uniwersytetu Śląskiego, Katowice 2015, vol. 20, pp. 14-15.

[6] Gajdzica Z., Mrózek S., Cele i zadania działań edukacyjnych w obszarze ksztatcenia uczniów z niepetnosprawnością oraz edukacji o niepetnosprawności zawarte w strategiach rozwoju gmin a problem rozwoju edukacji inkluzyjnej, [in:] „Studia Pedagogiczne. Wokół wyzwań pedagogicznych", ed. by Z. Gajdzica, vol. LXX, Polska Akademia Nauk. Komitet Nauk Pedagogicznych, Cieszyn 2017.

[7] Głąbicka K., Strategie rozwiazywania problemów społecznych jako przykład realizacji lokalnej polityki społecznej, „Wrocławskie Studia Politologiczne”, 15/2013, p. 190. 
[8] Grewiński M., Wieloaspektowa polityka społeczna. O przeobrażeniach państwa opiekuńczego, Wyższa Szkoła Pedagogiczna Towarzystwa Wiedzy Powszechnej w Warszawie, Warszawa 2009.

[9] Grewiński M., Karwacki A., Strategia - istota, reguty i wyzwania implementacji ze środowiska biznesu do polityki spotecznej, [in:] Strategie w polityce społecznej, ed. by M. Grewiński, A. Karwacki, publication co-financed from resources of the European Social Fund as part of the Human Capital Operational Programme, priority VII, activity 7.1.3., Mazowieckie Centrum Polityki Społecznej, Warszawa, 2011, pp. 16-18.

[10] Grochmal-Bach B., Czyż A., Skoczek A. (ed.), Segregacja. Integracja. Inkluzja, Akademia Ignatianum, Wydawnictwo WAM, Kraków 2013.

[11] Kołaczek B., Polityka spoteczna wobec osób niepetnosprawnych, Instytut Pracy i Spraw Socjalnych, Warszawa 2010.

[12] Kołomycew A., Kotarba B., Interes polityczny w realizacji polityki oświatowej, Wydawnictwo Naukowe SCHOLAR, Warszawa 2018.

[13] Lejzerowicz M., Książkiewicz A., Osoba z niepetnosprawnościa a instytucje pomocowe, Wydawnictwo Gaskor, Wrocław 2012.

[14] Lipiński A., Strategie rozwoju lokalnego, [in:] „Strategie rozwiązywania problemów społecznych w subregionie radomskim", ed. by K. Głąbicka, Biuletyn Informacji PTPS, Ramom 2011, p. 27.

[15] Obłój K., Trybuchowski M., Zarządzanie strategiczne, [in:] „Zarządzanie. Teoria i praktyka", ed. by A.K. Koźmiński, W. Piotrowski, Wydawnictwo Naukowe PWN, Wydanie piąte zmienione, Warszawa 2006, p. 127.

[16] Pawłowska E., Strategia rozwiazywania problemów spotecznych - nowa jakość ustug społecznych w Szklarskiej Porębie, [in:] „Środowiskowe usługi społeczne - nowa perspektywa polityki i pedagogiki społecznej", ed. by M. Grewiński, B. Skrzypczak, Wyższa Szkoła Pedagogiczna TWP w Warszawie, Warszawa 2011, p. 294.

[17] Radziejewska M., Mazurczak A., Konwencja o Prawach Osób Niepetnosprawnych. Poradnik RPO, Biuro Rzecznika Praw Obywatelskich, Warszawa 2013.

[18] Simon H.A., Działanie administracji, PWN, Warszawa 1976.

[19] Szczepaniak K., Zastosowanie analizy treści w badaniach artykutów prasowych refleksje metodologiczne, "Acta Universitatis Lodziensis Folia Sociologica”, Wydawnictwo Uniwersytetu Łódzkiego, no. 42/2012.

[20] Trawkowska D., Dziatania pozorne w pomocy społecznej - przypadek (i przypadtość) pracy socjalnej, „Problemy polityki społecznej. Studia i dyskusje”, 10/2007, Dom Wydawniczy „Elipsa”, Warszawa 2007.

[21] Wołowiec T., Reśko D., Strategia rozwoju gminy jako narzędzie zarzadzania zmianq gospodarcza, "Zeszyty Naukowe WSEI seria: EKONOMIA", 5(2/2012).

[22] Zajadacz A., Śniadek J., Modele niepetnosprawności jako determinanty przeobrażeń struktury podażowej rynku turystycznego dostępnego dla osób niepetnosprawnych, 
[in:] „Ewolucja podaży i popytu w turystyce”, ed. by B. Walas, J. Sobczuk, Wydawnictwo Wyższej Szkoły Turystyki i Ekologii, Sucha Beskidzka, 2014, pp. 215-216.

List of analysed strategies

Strategy of Integration and Solution of Social Problems of the commune of Czernichów for the years 2019-2029, <http://www.gops.czernichow.com.pl/pliki/Strategia\%20 rozwi $\%$ C4\%85zywania $\% 20$ problem $\%$ C3\%B3w \% 20spo\%C5\%82ecznych_PRO JEKT.pdf> [access: 25.04.2019].

Development Strategy of the Commune of Gilowice for the years 2015-2022, <http://www. gilowice.pl/zdjecia/ak/zal/strategia-gilowice_201511171402.pdf> [access: 25.04.2019].

Strategy for Solving Social Problems in the Commune of Gilowice for the years 2008-2020, <http://mapa-reagujemy.slask.pl/wp-content/uploads/2013/12/STRATEGIA_ 2008-20_GILOWICE.pdf> [access: 25.04.2019].

Development Strategy of the Commune of Jeleśnia for the years 2015-2020, <http:/ /www. jelesnia.pl/zdjecia/ak/1494/strategia-jelesnia-ver-4_201512211141.pdf> [access: 25.04.2019].

Strategy for Solving Social Problems in the Commune of Jeleśnia for the years 2013-2017, <http://www.bip.jelesnia.pl/index.php?modul=aktualnosci\&kat_id=122\&id= 4466> [access: 25.04.2019].

Strategy for Solving Social Problems in the Commune of Koszarawa for the years 2016-2020, <http:/ / bip.gwkoszarawa.finn.pl/res/serwisy/pliki/13492422?version=1.0> [access: 28.04.2019].

Development Strategy of the Commune of Lipowa do 2020 roku, <http://www.lipo wa.pl/assets/lipowa/media/files/d2878fcf-11a9-4cb9-8411-0f4e05f77c12/stra tegia-rozwoju-gminy-lipowa-projekt.pdf> [access: 28.04.2019].

Strategy of Integration and Solution of Social Problems of the commune of Lipowa for the years 2018-2023, <http://bip.lipowa.pl/uchwala-no--xliv-324-18-rady-gminy-li powa-z-dnia-25-stycznia-2018-r-w-sprawie-przyjecia-strategii-rozwiazywaniaproblemow-spolecznych-gminy-lipowa-na-lata-2018-2023> [access: 28.04.2019].

Development Strategy of the Commune of Łodygowice for the years 2014-2020, <http:/ / www. lodygowice.pl/i/images/file/bar573.pdf> [access: 28.04.2019].

Strategy for Solving Social Problems in the Commune of Łodygowice for the years 2014-2024, $<$ http://www.lodygowice.pl/!data/dokumenty/program\%20pomocy\%20dziec $\mathrm{ku} \% 20 \mathrm{i} \%$ 20rodzinie.pdf> [access: 28.04.2019].

Development Strategy of the Commune of Łękawica for the years 2014-2025, <www.bip. lekawica.com.pl/upl-zal.php?id=5344> [access: 29.04.2019].

Strategy for Solving Social Problems for the Commune of Łękawica for the years 2016-2025, <http:/ / www.bip.lekawica.com.pl/index.php?modul=aktualnosci\&kat_id=309 \&id=2792> [access: 29.04.2019]. 
Development Strategy of the Commune of Milówka for the years 2015-2025, <www.milow ka.pl/download/257.html> [access: 29.04.2019].

Strategy of Integration and Solution of Social Problems in the Commune of Milowk for the years 2014-2020, <http:/ / www.bip.milowka.com.pl/BIP.aspx?Sel=5845\&ident= 5240\&amp;js=1> [access: 29.04.2019].

Development Programme for the Commune of Radziechowy-Wieprz for the years 2016-2027, <http://www.radziechowy-wieprz.pl/upload/statement/22/files/422/programrozwoju-gminy-radziechowy-wieprz-na-lata-2016-2027.pdf> [access: 29.04.2019].

Strategy for Solving Social Problems in the Commune of Radziechowy-Wieprz for the years 2014-2020, <http://gopswieprz.pl/wp-content/uploads/2017/07/STRATEGIA2014-2020-pdf.pdf> [access: 29.04.2019].

Development Strategy of the Commune of Rajcza for the years 2014-2020, <http:/ / www. rajcza.pl/zdjecia/ak/zal/strategia-12-11-2015_201511131334.pdf> [access: 29.04.2019].

Development Strategy of the Commune of Ślemien for the years 2014-2022, <http://sle mien.pl/images/Artyku\%C5\%82/Za\%C5\%82\%C4\%85cznik_do_uchwa\%C5\% 82y_VIII.33.2015.pdf> [access: 29.04.2019].

Strategy for Solving Social Problems of the commune of Ślemien for the years 2008-2015, <http://ugslemien.bip.org.pl/pliki/ugslemien/ug_20140122_00000.pdf> [access: 29.04.2019].

Development Strategy of the Commune of Świnna for the years 2015-2022, <http:/ / www. archiwum.swinna.pl/upload/file/Strategia-\%C5\%9Awinna_16_11_2015.pdf> [access: 29.04.2019].

Strategy of Integration and Solution of Social Problems of the commune of Świnna for the years 2015-2020, <http://mapa-reagujemy.slask.pl/mapa/swinna/> [access: 29.04.2019].

Strategy for Solving Social Problems of the commune of Ujsoty for the years 2014-2020, <http://www.bip-gops.ujsoly.com.pl/index.php?modul=aktualnosci\&kat_id= 11\&id=31> [access: 30.04.2019].

Development Strategy of the Commune of Wegierska Górka for the years 2018-2025, <https://www.bip.wegierska-gorka.pl/index.php?modul=aktualnosci\&kat_id $=321 \& \mathrm{id}=3027>$ [access: 30.04 .2019$]$.

Strategy of Integration and Solution of Social Problems of the commune of Wegierska Górka for the years 2014-2020, <http://www.bip.wegierska-gorka.pl/index.php?mo dul=aktualnosci\&kat_id=230\&id=2132> [access: 30.04.2019].

Strategy of Sustainable Socio-Economic Development of the County of Żywiec for the years 2006-2020, <https://bip-pzzywiec.finn.pl/res/serwisy/bip-pzzywiec/komuni katy/_007_002_405638.pdf> [access: 30.04.2019].

Strategy for Solving Social Problems for the city of Żywiec for the years 2014-2020, <http:// www.bip.zywiec.pl/index.php?modul=aktualnosci\&kat_id=54\&id=3597> [access: 30.04.2019]. 
Development Strategy of the Commune of Brenna do 2020 roku, <http:/ / www.bip.bren na.org.pl/?c=mdTresc-cmPokaz-189> [access: 02.05.2019].

Strategy for Solving Social Problems in the Commune of Brenna for the years 2014-2020, $<$ www.bip.brenna.org.pl/?c=mdPliki-cmPobierz-8092> [access: 02.05.2019].

Development Strategy of the Commune of Chybie for the years 2015-2025, <http:/ /www. chybie.pl/asp/pliki/aktualnosci/2016_03_02_strategia_gminy_chybie.pdf> [access: 02.05.2019].

Gminna Strategy for Solving Social Problems of the commune of Chybie for the years 20142020, <http://www.mapa-reagujemy.slask.pl/wp-content/uploads/.../Chybie _STRATEGIA2015-2022.doc> [access: 02.05.2019].

Development Strategy for the City of Cieszyn for the years 2010-2020, <http://www. cieszyn.pl/?p=categoriesShow\&iCategory=158> [access: 02.05.2019].

Commune Strategy for Solving Social Problems of the City of Cieszyn for the years 20142020 <http:/ / mapa-reagujemy.slask.pl/wp-content/uploads/2013/11/strategia_ 2014_20_cieszyn.pdf> [access: 02.05.2019].

Development Strategy of the Commune of Debowiec for the years 2016-2025, <http:/ / www. debowiec.bip.info.pl/dokument.php?iddok $=4353 \& i d m p=102 \& r=r>$ [access: 02.05.2019].

Strategy for Solving Social Problems in the Commune of Dębowiec for the years 2012-2020, <http://mapa-reagujemy.slask.pl/wp-content/uploads/2013/11/Strategia-Roz wi \%C4\%85zywania-Problem \% C3\%B3w-Spo \% C5\%82ecznych-w-Gminie-D\% C4 \%99bowiec-na-lata-2012-2020.pdf> [access: 02.05.2019].

Strategy for Solving Social Problems of the commune of Goleszów for the years 2016-2020, <http:/ / www.gops-goleszow.pl/files/Zarzadzenie\%20nr\%200050.102.2016.pdf> [access: 04.05.2019].

Development Strategy of the Commune of Goleszów for the years 2016-2026, <http:/ / www. goleszow.bip.net.pl/?a=9914> [access: 04.05.2019].

Development Strategy of the Commune of Hazlach for the years 2011-2020, <http:/ / www. hazlach.samorzady.pl/art/id/3004> [access: 04.05.2019].

Strategy for Solving Social Problems of the commune of Hażlach for the years 2011-2020, <http:/ / mapa-reagujemy.slask.pl/wp-content/uploads/2013/11/Strategia_Roz wi \% C4\% 85zywania-Problem \% C3\%B3w-Spo\%C5\%82ecznych-wraz-z-programa mi.pdf> [access: 04.05.2019].

Commune of Istebna, Development Strategy 2020, <http://e-bip.pl/Start/23464/Infor mation/222667> [access: 04.05.2019].

Commune Strategy for Solving Social Problems in the Commune of Istebna for the years 2016-2022, <www.istebna.bip.info.pl/plik.php?id=7857> [access: 04.05.2019].

Development Strategy of the Commune of Skoczów for the years 2014-2020, <http:/ / bip. skoczow.pl/uchwala-no.-xli-528-2014-w-sprawie-przyjecia-startegii-rozwoju-gmi ny-skoczow-na-lata-2014-2020/porownaj/3/2> [access: 04.05.2019]. 
Strategy for Solving Social Problems for the Commune of Skoczów for the years 2014-2020, <http:/ / bip.skoczow.pl/uchwala-no.-xxxv-454-2013-w-sprawie-przyjecia-gmin nej-strategii-rozwiazywania-problemow-spolecznych-dla-gminy-skoczow-na-la ta-2014-2020> [access: 04.05.2019].

Strategy of Development of the City and Commune of Strumien for the years 2014-2022, <http://www.strumien.bip.net.pl/?c=338> [access: 04.05.2019].

Strategy for Solving Social Problems in the Commune of Strumien for the years 2011-2018, <http://mapa-reagujemy.slask.pl/wp-content/uploads/2013/11/STRATEGIA_ 2011_18_STRUMIEN.pdf> [access: 04.05.2019].

Development Strategy for the City of Ustron until the year 2020, <http://www.zglosze nia.ustron.pl/media/page/332/attachment/Strategia\%20Rozwoju\%20Miasta\% 20Ustro\%C5\%84\%20do\%202020\%20roku.pdf> [access: 04.05.2019].

Strategy for Solving Social Problems of the commune of Ustron for the years 2016-2020, $<$ www.ustron.bip.info.pl/plik.php?id=33648> [access: 04.05.2019].

Development Strategy for the City of Wista until the year 2020, <http://docplayer.pl/ 10805945-Strategia-rozwoju-miasta-wisla-na-lata-2014-2022-1-s-t-r-o-n-a.html> [access: 04.05.2019].

Commune Strategy for Solving Social Problems in the City of Wista for the years 2016-2024, <http://www.prawomiejscowe.pl/api/file/GetZipxAttachment/254/501233/ preview> [access: 04.05.2019].

Development Strategy of the Commune of Zebrzydowice until the year 2020, <http:/ /www. zebrzydowice.bip.info.pl/dokument.php?iddok $=6794 \& i d m p=77 \& r=r>$ [access: 04.05.2019].

Strategy for Solving Social Problems of the commune of Zebrzydowice for the years 2011-2017, <www.zebrzydowice.bip.info.pl/dokument.php?iddok=4260\&idmp= $8 \& \mathrm{r}=\mathrm{r}>$ [access: 04.05.2019]. 